Al-Uqud: Journal of Islamic Economics Volume 4 Issue 2, July 2020

E-ISSN 2548-3544, P-ISSN 2549-0850 DOI:10.26740/al-uqud.v4n2.p200-207

Accredited No. 28/E/KPT/2019

Page 200-207

\title{
Factors Affecting Tourist Interest on Sharia Tourism
}

\section{Popon Srisusilawati*}

${ }^{1}$ Department of Islamic Banking, Faculty of Sharia, Universitas Islam Bandung, Jalan Tamansari No.1, Tamansari, Bandung, Jawa Barat 40116

Abstract: Sharia tourism is part of the halal industry which becomes one of the major supporters of the sharia economy in Indonesia. Nevertheless, since 2011, the city of Bandung as the epicentrum of sharia tourism experienced a decreasing number of visitors. The purpose of this study is to analyze the factors that influence tourist interest in visiting sharia tourism destinations. The research method is quantitative. The results of this study indicate that service, safety, and tourism influence tourist interest. The safety and promotion factors significantly influence tourist interest in visiting Sharia tourism, while service has no significant effect on tourist interest.

Keywords: Decision-making factors; Sharia Tourism; Tourist.

Paper type: Research paper

*Corresponding author: po2nss@gmail.com

Received: March 26, 2020; Accepted: April 22, 2020; Available online: May 14, 2020; Published regularly: July 2020

Cite this document: Srisusilawati, P. (2020). Factors Affecting Tourist Interest on Sharia Tourism. Al-Uqud: Journal of Islamic Economics, 4(2), 200-207. doi: http://dx.doi.org/10.26740/al-uqud.v4n2.p200-207

Copyright ( 2020, Al-Uqud: Journal of Islamic Economics http://journal.unesa.ac.id/index.php/jie 


\begin{abstract}
Abstrak: Pariwisata syariah merupakan bagian dari industri halal yang merupakan salah satu penyokong besar terhadap perkonomian syariah di Indonesia. Namun kota Bandung sebagai salah satu pariwisata syariah yang memiliki destinasi yang potensial, sejak tahun 2011 mengalami penurunan jumlah pengunjung. Tujuan penelitian ini adalah untuk menganalisis faktor yang mendukung minat berkunjung di destinasi pariwisata syariah. Metode yang digunakan adalah kuantitatif. Hasil dalam penelitian ini bahwa keamanan serta kenyamanan dan promosi berpengaruh secara signifikan terhadap minat wisatawan terhadap wisatawan yang berkunjung ke destinasi pariwisata syariah, namun hal ini tidak berpengaruh terhadap pelayanan. Tetapi secara keseluruhan bahwa semua faktor berpengaruh terhadap minat berkunjung.
\end{abstract}

Kata kunci: Faktor pengambilan keputusan; Pariwisata Syariah; Wisatawan

\title{
INTRODUCTION
}

Tourism is one of the sectors that significantly contribute to the economic development of a country (Astina \& Artani, 2017; Nonthapot, 2016). Halal or sharia tourism that operated by Muslim or Islamic societies started to bloom following the growing tourism business in Indonesia. The entire Islamic tourism sector has positive implications for the increased income of the community and influences the well-being of the people themselves (Ramadhany \& Ridlwan, 2018). Sharia tourism contributed to Indonesia's GDP in 2004-2009 (Mudrikah, 2014). Furthermore, Agro-tourism management had a positive impact on economic and social life (Retnoningsih, 2013; Stephenson \& Ali-Knight, 2010).

Sharia tourism which is expected to provide a significant contribution to the sharia economy is essential to be improved by continuously increasing interest in visiting from tourists. Tourists interest is influential in choosing a destination that will be visited. In their research, Hakim and Nugroho said that the factors influencing the interest of visiting tourists are the challenges, the beauty of the panoramic view (Hakim \& Nugroho, 2018). While Popescu's research explained that when the ease of access is obtained, tourist security in enjoying tourism is the most crucial thing (Popescu, 2011). Meanwhile, other studies state that the transportation service model is an attraction for tourists to visit destinations (Khan, et al., 2017; Suid, Mohd Nor, \& Omar, 2017). Margaret also stated that service, security and attractiveness affect the interest of tourists to Mahawu Mountain tourism objects (Denstadli \& Jacobsen, 2011; Sondakh \& Tumbel, 2016), while Sutanto examined the importance of promotion in order to increase tourist interest in the old city Semarang (Folgado-Fernández, Campón-Cerro, \& HernándezMogollón, 2019; Horng \& (Simon) Tsai, 2010; Sutanto, 2016).

However, research on decision making on tourist interests to visiting sharia tourism destination, has not examined the yet. Therefore, this study is important because decision making factors are very important to understood by sharia tourism players in order to attract more visitors. Tas a result, this research examines the issue to fill the literature gap in sharia marketing studies. Furthermore, the novelty of research lies in the research focus on tourist interest toward sharia tourism, especially factors which influence the tourist decision making process before visiting to sharia tourism. 
This research develops a literature research in the process of identifying decision making process of tourist's interest. Three main variables are studied as forming variables of tourist interest (decision making) (Sondakh \& Tumbel, 2016) are promotion (Andika \& Susanti, 2018; Rahmi, Kahar, \& Karnay, 2017; FolgadoFernández, Campón-Cerro, \& Hernández-Mogollón, 2019; Horng \& (Simon) Tsai, 2010; Al-Badi, Tarhini, \& Al-Sawaei, 2017; Carboni \& Janati, 2016; Iosim, 2013; Sami, 2017) and comfort and security (Suputera \& Mahagangga, 2016; Denstadli \& Jacobsen, 2011; Özdemir \& Seyitoğlu, 2017; Moreno, 2010; Imboden, 2012; Moyo \& Ziramba, 2013), services (Rosita, Marhanah, \& Wahadi, 2016; Khan et al., 2017; Suid, Mohd Nor, \& Omar, 2017; Kandampully, 2000; Liu, Tzeng, Lee, \& Lee, 2013; Bhat, 2012).

In principle, this study examines and tries to find the majority and important factors that influence tourist interest in Islamic tourism. The primary variables examined in this study are limited based on the findings of previous research that examines tourist decision making.

The objectives in this study will analyze the factors that influence interest in determining sharia tourism destinations, so that the industry players could use to determine strategy to attract more visitors to their tourism destination.

Based on the explanation above, the hypothesis are:

$\mathrm{H} 1=$ Promotion, safety and comfort, service are simultaneously influence tourist interest.

$\mathrm{H} 2=$ Promotion is partially influence tourist interest.

H3 = Safety and comfort are partially influence tourist interest.

$\mathrm{H} 4=$ Service is partially influence tourist interest.

\section{RESEARCH METHODS}

This type of research is a quantitative descriptive research that reveals the location of the tourism area of Little Seoul and Rabbit Town, Bandung. The type of data is quantitative data as a collection of numerical data that are considered responsive about the consumer behaviour (tourist interest) in visiting Little Seoul and Rabbit Town.

The population in this study were all tourists visiting destinations in the city of Bandung. The sampling method was non-probability sampling, in the form of purposive sampling that selecting sample based on criteria determined by researchers. The sample used in this study was only tourists who visited Little Seoul Bandung and Rabbit Town because these destinations were popular at the moment. Therefore, researchers took samples of 100 tourists who visited these destinations on Saturday and Sunday.

The analysis of linear regression and the use of the methods used in describing the relationship between a variable is bound to two or more variables. Regression analysis is used to find the degree of dependence of one variable on another variable or more. This analysis of regression allows researchers to conclude the impact of different variables on the dependent variable. The independent variable here is decision making which consists of promotion (X1), security and comfort (X2) and service (X3) while the dependent variable is tourist interest (Y). 


\section{RESULTS AND DISCUSSION}

Based on the results of data tabulation, it can be concluded from 100 respondents, women is a dominant gender in the sample about 72 people $(72 \%)$, while male respondents are about 38 people $(38 \%)$. The age of respondents that were mostly found in this study were those between $18-25$ years about 68 people $(68 \%)$ and the rest were mixed of all age category.

In this study, multiple linear regression analysis is presented as follows:

Table 1. Analysis of Multiple Regression and Partial T-test (t)

\begin{tabular}{lrr}
\hline \multicolumn{1}{c}{ Variable } & t & \multicolumn{1}{c}{ Sig. } \\
\hline Service (X1) & 2.392 & .019 \\
Safety (X2) & .984 & .328 \\
Promotion (X3) & 2.739 & .007 \\
\hline
\end{tabular}

Source: Processed by author, 2019

In this research, partial results (tests) can be seen in table 1. Based on the above data, it shows that the hypothetical hypotheses are as follows:

1. Service variable is partially tested and shows $\mathrm{H} 0$ is accepted or $\mathrm{H} 4$ is rejected due to significance value about $(0.328>0.05)$. It can be said that the variability of services are not significantly influence visiting interest.

2. The safety and comfort variables are partially tested and show $\mathrm{H} 0$ is rejected or H3 is accepted due to sgnificance value about $(0.007<0.05)$. It can be said that the variable safety and comfort have a significant and positive effect on visiting interest.

3. The variable of promotion is partially tested and shows $\mathrm{H} 0$ is rejected or $\mathrm{H} 2$ accepted due to significance value about $(0,000<0.05)$. It can be said that promotion has significant and positive effect on visiting interest.

In this research, hypothesis testing is done to ensure the effect of service, safety and comfort and promotion of the interests of Muslim tourists with the analysis used is multiple linear regression for forecasting the influence of several independent variables on the dependent variable and to prove the presence or absence of functional relationships between independent variables relationship. The equation of this relationship is formulated as follows:

$$
\mathrm{Y}=\mathrm{b} 0+\mathrm{b} 1 \mathrm{X} 1+\mathrm{b} 2 \mathrm{X} 2+\mathrm{b} 3 \mathrm{X} 3+\mathrm{e}
$$

Note:

$\mathrm{Y}=$ Tourist Interest

$\mathrm{X} 1$ = Service

$\mathrm{X} 2=$ Safety and comfort

$\mathrm{X} 3$ = promotion

$\mathrm{b}=$ Interception

$\mathrm{e}=$ Disturbing Factors 
From the results of Multiple Linear Regression analysis, it can be known that every time, there is a change in safety and comfort as well as the promotion, it will influence tourist interest who visit Little Soul and Rabbit Town. This is in line with his research Andika \& Susanti (2018); Al-Badi, Tarhini, \& Al-Sawaei (2017); Carboni \& Janati (2016); Folgado-Fernández, Campón-Cerro, \& Hernández-Mogollón (2019); Horng \& (Simon) Tsai (2010); Iosim (2013); Rahmi, Kahar, \& Karnay (2017); Sami (2017); Denstadli \& Jacobsen (2011); Imboden (2012); Moreno (2010); Moyo \& Ziramba (2013); Özdemir \& Seyitoğlu (2017) which stated that promotion is an important thing that can influence interest tourists to visit. This is supported by research Fahrudin \& Yulianti (2015); Rahmi, Kahar, \& Karnay (2017); Sangkaeng, Mananeke, \& Oroh (2015); Hakim \& Nugroho (2018); Suputera \& Mahagangga (2016) which concluded that safety is an important thing that can increase visitor interest and increase a visitor's loyalty, but has no effect on service. This research contradict the research of Bhat (2012); Kandampully (2000); Liu, Tzeng, Lee, \& Lee (2013); Khan et al. (2017); Rosita, Marhanah, \& Wahadi (2016); Suid, Mohd Nor, \& Omar (2017) which state service is the most influential factor of tourist interest.

Table 2. Correlation Coefficient and Determination

\begin{tabular}{|r|r|r|r|}
\hline \multicolumn{1}{|c|}{ Model } & R & R Square & Adjusted R Square \\
\hline 1 & $.615^{\mathrm{a}}$ & .366 & .242 \\
\hline
\end{tabular}

a. Predictors: (Constant), Service-X1, Safety-X2, Promotion-X3,

Source: Processed by author, 2019

The results of the regression analysis implies correlation coefficient (R) of 0.615 or $61.5 \%$ which indicate the strong relationship between service, safety and promotion with tourist interest as $\mathrm{R}$ value about above 0.5 . This result supports Sondakh \& Tumbel (2016) that promotion, security and comfort and service have a strong relationship. Meanwhile the coefficient $\left(\mathrm{R}^{2}\right)$ about 0.366 shows that the factors affecting tourist interest can be explained by three independent variables of service, safety and comfort and promotion about $36.6 \%$ as presented in table 3 above, while the rest is explained by another variables outside the research model.

Based on the analysis of the factors that affect the tourist interest in visiting the Little Seoul and Rabbit Town in Bandung city, West Java Province, when security and comfort are increased, tourist interest in visiting these destinations will increase. Moreover, when the sharia tourism destination provides an attractive promotion, this will attract more tourist to this placre.

\section{CONCLUSION}

Based on the results of the research and discussion, it can be conluded that every change in safety, comfort and service will affect the tourist interest on attractions and the visitors of Little Seoul Bandung and Rabbit Town in the City of West Java Province. Service, safety and comfort and promotion are simultaneously affect the interest of visiting sharia tourism in the Little Seoul Bandung and Rabbit Town in Bandung. 
Therefore, the factors that influence the tourist interest in visiting these destinations should be further improved so that the number tourist visitors to the city of Bandung will be increase as well. It is recommended to the management of Little Seoul Bandung and Rabbit Town in Bandung to further enhance the promotion, safety and comfort of tourists so that this will be able to increase the number of tourists and provide better service so that it will increase the comfort of tourists who visit these destinations.

\section{REFERENCES}

Al-Badi, A., Tarhini, A., \& Al-Sawaei, S. (2017). Utilizing social media to encourage domestic tourism in Oman. International Journal of Business and Management, 12(4), 84-94. https://doi.org/10.5539/ijbm.v12n4p84

Andika, A., \& Susanti, F. (2018). Pengaruh Marketing Mix Terhadap Keputusan Pembelian Parfum di Azzwars Parfum Lubeg Padang. INA-Rxiv Papers. https://doi.org/10.31227/osf.io/upgc3

Astina, M. A., \& Artani, K. T. B. (2017). Dampak Perkembangan Pariwisata Terhadap Kondisi Sosial dan Ekonomi Masyarakat Sanur. Jurnal Ilmiah Hospitality Management, $\quad 7(2), \quad$ 141-146. https://doi.org/10.22334/JIHM.V7I2.9

Bhat, M. A. (2012). Tourism Service Quality: A Dimension-specific Assessment of SERVQUAL *. Global Business Review, 13(2), 327-337. https://doi.org/10.1177/097215091201300210

Carboni, M., \& Janati, M. I. (2016). Halal tourism de facto: A case from Fez. Tourism Management Perspectives, Vol. 19, pp. 155-159. https://doi.org/10.1016/j.tmp.2015.12.007

Denstadli, J. M., \& Jacobsen, J. K. S. (2011). The long and winding roads: Perceived quality of scenic tourism routes. Tourism Management, 32(4), 780789. https://doi.org/10.1016/j.tourman.2010.06.014

Fahrudin, M. F., \& Yulianti, E. (2015). Pengaruh promosi, lokasi, dan kualitas layanan terhadap keputusan pembelian nasabah Bank Mandiri Surabaya. Journal of Business \& Banking, 5(1), 149-162. http://dx.doi.org/10.14414/jbb.v5i1.478

Folgado-Fernández, J. A., Campón-Cerro, A. M., \& Hernández-Mogollón, J. M. (2019). Potential of olive oil tourism in promoting local quality food products: A case study of the region of Extremadura, Spain. Heliyon, 5(10). https://doi.org/10.1016/j.heliyon.2019.e02653

Hakim, M. F. N., \& Nugroho, D. S. (2018). Faktor Yang Mempengaruhi Wisatawan Untuk Menikmati Wisata Minat Khusus ( Study kasus Goa Cerme ). Khasanah Ilmu - Jurnal Pariwisata Dan Budaya, 9(2). https://doi.org/10.31294/khi.v9i2.5229

Horng, J. S., \& (Simon) Tsai, C. T. (2010). Government websites for promoting East Asian culinary tourism: A cross-national analysis. Tourism Management, 31(1), 74-85. https://doi.org/10.1016/j.tourman.2009.01.009 
Imboden, A. (2012). Between Risk and Comfort: Representations of Adventure Tourism in Sweden and Switzerland. Scandinavian Journal of Hospitality and Tourism, 12(4), 310-323. https://doi.org/10.1080/15022250.2012.752624

Iosim, I. (2013). The Contribution Of Tourist Promotion Associations Federation In Promoting Romanian Agro-Tourism. Research Journal of Agricultural Science, 45(4), 95-98. Retrieved from http://www.federatiaturism.ro/

Kandampully, J. (2000). The impact of demand fluctuation on the quality of service: A tourism industry example. Managing Service Quality: An International Journal, 10(1), 10-19. https://doi.org/10.1108/09604520010307012

Khan, S. A. R., Qianli, D., SongBo, W., Zaman, K., \& Zhang, Y. (2017). Travel and tourism competitiveness index: The impact of air transportation, railways transportation, travel and transport services on international inbound and outbound tourism. Journal of Air Transport Management, 58, 125-134. https://doi.org/10.1016/j.jairtraman.2016.10.006

Liu, C. H., Tzeng, G. H., Lee, M. H., \& Lee, P. Y. (2013). Improving metro-airport connection service for tourism development: Using hybrid MCDM models. Tourism Management Perspectives, 6, 95-107. https://doi.org/10.1016/j.tmp.2012.09.004

Moreno, A. (2010). Mediterranean tourism and climate (change): A survey-based study. Tourism and Hospitality, Planning and Development, 7(3), 253-265. https://doi.org/10.1080/1479053X.2010.502384

Moyo, B., \& Ziramba, E. (2013). The impact of crime on inbound tourism to South Africa: An application of the bounds test. African Security Review, 22(1), 4 18. https://doi.org/10.1080/10246029.2012.737815

Mudrikah, A. (2014). Kontribusi Sektor Pariwisata Terhadap Gdp Indonesia Tahun 2004 - 2009. Economics Development Analysis Journal, 3(2). https://doi.org/10.15294/edaj.v3i2.3844

Nonthapot, S. (2016). Mediation Between Tourism Contribution and Economic Growth in the Greater Mekong Subregion. Asia Pacific Journal of Tourism Research, 21(2), 157-171. https://doi.org/10.1080/10941665.2015.1029953

Özdemir, B., \& Seyitoğlu, F. (2017). A conceptual study of gastronomical quests of tourists: Authenticity or safety and comfort? Tourism Management Perspectives, 23, 1-7. https://doi.org/10.1016/j.tmp.2017.03.010

Popescu, L. (2011). Safety and Security in Tourism. Case Study: Romania. 10(2), 322-328. https://doi.org/10.5775/fg.2067-4635.2011.020.d

Rahmi, S. N., Kahar, K., \& Karnay, S. (2017). Aktivitas Promosi Toraja Destination Management Organization (Dmo) Dalam Mempromosikan Objek Wisata Di Toraja. Kareba: Jurnal Ilmu Komunikasi, 5(1), 49-58. https://doi.org/10.31947/KJIK.V5I1.1882

Ramadhany, F., \& Ridlwan, A. A. (2018). Implikasi Pariwisata Syariah Terhadap Peningkatan Pendapatan dan Kesejahteraan Masyarakat. Muslim Heritage, 3(1), 157. https://doi.org/10.21154/muslimheritage.v3i1.1303

Retnoningsih, E. (2013). Dampak Pengelolaan Wisata Agro Terhadap Kehidupan Sosial Dan Ekonomi Masyarakat (Studi Kasus: Kebun Teh Kaligua Desa Pandansari Kab Brebes Jawa Tengah). Khasanah Ilmu - Jurnal Pariwisata 
Dan Budaya, 4(1). https://doi.org/10.31294/KHI.V4I1.466

Rosita, R., Marhanah, S., \& Wahadi, W. H. (2016). Pengaruh Fasilitas Wisata Dan Kualitas Pelayanan Terhadap Kepuasan Pengunjung Di Taman Margasatwa Ragunan Jakarta. Pengaruh Fasilitas Wisata Dan Kualitas Pelayanan Terhadap Kepuasan Pengunjung Di Taman Margasatwa Ragunan Jakarta, 13(1). https://doi.org/10.17509/jurel.v13i1.2134

Sami, A. (2017). Role of Social Media in Promoting Education Tourism. Article in Journal of Computational and Theoretical Nanoscience. https://doi.org/10.1166/asl.2017.9959

Sangkaeng, S., Mananeke, L., \& Oroh, S. G. (2015). Pengaruh Citra, Promosi Dan Kualitas Pelayanan Objek Wisata Terhadap Kepuasan Wisatawan Di Objek Wisata Taman Laut Bunaken Sulawesi Utara. Jurnal EMBA: Jurnal Riset Ekonomi, Manajemen, Bisnis Dan Akuntansi, 3(3). https://doi.org/10.35794/EMBA.V3I3.10113

Sondakh, P. M. N. \& Tumbel, A. (2016). Pelayanan, Keamanan Dan Daya Tarik Mempengaruhi Minat Wisatawan Yang Berkunjung Ke Objek Wisata Alam Gunung Mahawu, Tomohon. Jurnal Berkala Ilmiah Efisiensi, 16(1), 280-288.

Stephenson, M. L., \& Ali-Knight, J. (2010). Dubai's tourism industry and its societal impact: Social implications and sustainable challenges. Journal of Tourism and Cultural Change, 8(4), 278-292. https://doi.org/10.1080/14766825.2010.521248

Suid, I. S., Mohd Nor, N. A., \& Omar, H. (2017). The Influence Of Inbound Muslim Travellers' Attitude On Travel Satisfaction Towards Revisit Intention To Malaysia: A Conceptual Framework. Journal Of Technical And Vocational Education, 1 (1). pp. 26-36.

Suputera, I. W. C., \& Mahagangga, I. G. A. O. (2016). Upaya Masyarakat Lokal Dalam Menjaga Keamanan Dan Kenyamanan Wisatawan Di Desa Adat Ubud (Studi Tindakan Sosial Dalam Pariwisata). Jurnal Destinasi Pariwisata, 4(2), 30. https://doi.org/10.24843/jdepar.2016.v04.i02.p06

Sutanto, D. H. (2016). Pentingnya Promosi Guna Meningkatkan Minat Wisatawan Wisata Sejarah Di Kota Lama Semarang. Jurnal Pariwisata Pesona, 1(1). https://doi.org/10.26905/jpp.v1i1.372 